\title{
WORK-LIFE-BALANCE BENEFITS AS BRAIN DRAIN PREVENTION
}

\author{
Eliška Nacházelová 1 id \\ Alice Reissová ${ }^{2}$ (iD
}

DOI: https://doi.org/10.31410/LIMEN.S.P.2020.85

\begin{abstract}
The contribution of highly qualified employees, not only for multinational companies, is unquestionable. Their eventual departure often has negative economic consequences, and their replacement is usually difficult and expensive. Therefore, it is important to pay increased attention to their stabilization. This article aims to find out which of the work-life balance area benefits are more important for the stabilization of IT employees in an international automotive company $(n=154)$. With the use of the Friedman test, it was found out that the most important benefit is flexible working hours. Based on the KruskalWallis test, the evaluation of the importance of individual benefits was further verified according to basic socio-economic factors (age, gender, length of employment). The right setting of benefits will give a competitive advantage in the search for new talent and at the same time serve as an effective tool against brain drain.
\end{abstract}

Keywords: Work-life-balance benefits, Retention of employees, IT employees, Brain drain, Brain gain.

\section{INTRODUCTION}

$\mathrm{H}$ ighly qualified employees form the basis of a company's economic success. They bring high added value and they are a source of innovations that are necessary not only to keep pace with the competition but also for further development. Therefore, the attention of human resources within talent management is focused not only on acquiring new, talented people, but also on their subsequent adaptation, motivation, job satisfaction and overall stabilization. A lack of talent is faced especially by international corporations, which show a growing interest in this group of employees (Przytuła, 2018). The positive effects of talent management have been repeatedly empirically demonstrated (Slavković, Babić, \& StojanovićAleksić, 2015; Crowley, Benson, \& Al Ariss, 2019; Meyer, \& Xin, 2018). However, in the area of talent management in companies, weaknesses that can result in the loss of these highly qualified employees are often identified. Vetráková et al. (2020) surveyed HR professionals and, based on the Delphi method, concluded that if talented employees receive an offer from another employer, they leave their current employer much more easily than other employees.

If the brain drain phenomenon occurs in a company and highly qualified employees leave, damage arises that may create a decline in competitive ability and subsequent negative economic impacts. Therefore, some studies aim to understand why people leave their jobs. Wage levels play an important role but it is not the only factor that people consider when making decisions. Other factors, such as secondary work responsibilities, work investment and

1 Department of Economy and Management of the Faculty of Social and Economic Studies, Jan Evangelista Purkyně University, 40096 Ústí nad Labem, The Czech Republic

2 Department of Economy and Management of the Faculty of Social and Economic Studies, Jan Evangelista Purkyně University, 40096 Ústí nad Labem, The Czech Republic 
moonlighting (i.e. the combination of two employments), are also important as well as job satisfaction (Zimmerman, Swider, \& Arthur, 2020). Highly qualified people, also referred to as inventors, are less geographically limited (Drivas, 2020) which in turn means that there is a brain drain not only from the company but also from the country.

In order to prevent brain loss, companies find out the level of satisfaction of their employees and look for such benefits that would increase it and, thus, increase also the probability of their staying with the current employer. At present, issues in the field of work-life-balance come to prominence. It has been found out that work-life balance in conjunction with workplace stress significantly affects the employee's intention to leave (Kerdpitak \& Jermsittiparsert, 2020). Long-term W-L-B imbalances have also been proven to negatively affect job satisfaction (Gragnano, Simbula, \& Miglioretti, 2020) but they also have negative health consequences (Mensah \& Adjei, 2020). The feeling of W-L-B imbalance is mostly influenced by working hours, the amount of free time the employee has for himself, subjective assessment of financial condition and others (Pawlicka et al., 2020 Bjärntoft et al., 2020). Based on detailed research, various models in the $\mathrm{W}$-L-B field, which have increasing job satisfaction and ensuring talent retention as its goal, are emerging (Rodríguez-Sánchez et. Al., 2020).

This article aims to find out which of the benefits in the W-L-B area is considered the most important for employees and whether there are statistically significant differences in the evaluation of these benefits with respect to basic socio-economic characteristics (gender, age, and length of employment).

\section{METHODOLOGY}

The research took place in a major multinational manufacturing company operating in the automotive field. In terms of optimal operation of the company, maintaining of competitive ability as well as development and benefits of future innovations, the brains include employees working in the IT department. The survey sample included 154 workers with a university degree. It consisted of 123 men and 31 women.

The W-L-B benefits that were taken into account in this survey include: nursery/kindergarten allowance, paid leave, extra leave, home office, flexible working hours.

To meet the goal, the following hypotheses were defined:

Hypothesis One: The most important of benefits that belong to the W-L-B area for stabilizing employees is flexible working hours.

Hypothesis Two: The relationship between age and the assessment of the importance of stabilization related benefits is statistically significant.

Hypothesis Three: The relationship between gender and the assessment of the importance of stabilization related benefits is statistically significant.

Hypothesis Four: The relationship between the number of years in a company and the assessment of the importance of stabilization related benefits is statistically significant.

The method of anonymous electronic inquiry was selected. Most of the questions were closed, the respondents answered on the Likert 7-point scale $(1=$ least, $7=$ most $)$. The questionnaire included, for example, the following question: Indicate how important are the following benefits in relation to your decision to stay in the company. 
The data were processed using Microsoft Office Excel and IBM SPS Statistics. The following statistical tests were used: Friedman test, Kruskal-Wallis test.

\section{RESULTS}

First, it was determined which benefit from the W-L-B area is most important for the stabilization of IT employees. As clearly shown in Table 1, the most important benefit is the flexible working hours which on the Likert scale $1-7$ reached an average value of 6.5. In second place was the extra leave benefit and the third was home office. The results show that respondents clearly prefer such benefits that allow them to organize their time, or possibly gain more free time.

Table 1. Importance of selected benefits

\begin{tabular}{|c|c|c|c|c|}
\hline Work-life Benefits & $\begin{array}{c}\emptyset \\
\text { importance }\end{array}$ & Rank & $\begin{array}{c}\text { K-related } \\
\text { samples } \\
\text { (Sig.) }\end{array}$ & $\begin{array}{c}\emptyset \\
\text { area }\end{array}$ \\
\hline Nursery/kindergarten allowance & 2.4 & 5. & & \\
Paid leave & 4.2 & 4. & & \\
Extra leave & 6.2 & 2. & $2.7 \mathrm{E}-85$ & 5.0 \\
Home office & 5.7 & 3. & & \\
Flexible working hours & 6.5 & 1. & & \\
\hline
\end{tabular}

Note: N=154; K-related samples - Friedman Test; Sig. = Significance

Source: Own calculation

The calculated values in the K-related samples column indicate statistical significance among the benefits at the 0.01 level. Hypothesis 1, which assumed that for the stabilization of employees the most important of the benefits that belong to the W-L-B area is flexible working hours, was confirmed.

The Kruskal-Wallis nonparametric test was used to determine differences in the assessment of the importance of benefits and socio-economic data.

First, it was examined whether there are differences in the assessment according to the age of the respondents. As can be seen in Table 2, there were significant differences in the assessment of the importance of nursery/kindergarten allowance and paid leave, which are more important for employees under 30. The evaluation of the importance of home office reached significance only at 0.1 level.

Table 2. Importance of benefits in relation to remaining in company - according to age

\begin{tabular}{|c|c|c|c|c|c|c|}
\hline Benefits & Age (years) & $\begin{array}{c}\text { Mean } \\
\text { Rank }\end{array}$ & Mean & $\begin{array}{c}\text { Standard } \\
\text { Deviation }\end{array}$ & $\begin{array}{c}\text { Kruskal- } \\
\text { Wallis H }\end{array}$ & Sig. \\
\hline $\begin{array}{c}\text { Nursery/ } \\
\text { kindergarten } \\
\text { allowance }\end{array}$ & $\begin{array}{c}<1-40 \\
41-50\end{array}$ & $\begin{array}{c}89.78 \\
87.34\end{array}$ & 2.4 & 1.7 & 15.2 & $0.002 * *$ \\
\hline & $>50$ & 64.30 & & & & \\
Paid leave & $31-40$ & 86.94 & & & & \\
& $41-50$ & 58.09 & 4.2 & 1.7 & 9.6 & $0.022^{*}$ \\
& $>50$ & 72.90 & & & & \\
\hline
\end{tabular}




\begin{tabular}{|c|c|c|c|c|c|c|}
\hline & $<30$ & 83.16 & & & & \\
Home office & $31-40$ & 83.05 & 5.7 & 1.8 & 6.4 & 0.092 \\
& $41-50$ & 71.70 & & & & \\
\hline
\end{tabular}

Note: $N=154 ;$ Correlation is significant at 0.05-*/0.01-** level; Sig. = Significance

Source: Own calculation

Thus, the second hypothesis, which assumed that the relationship between age and the assessment of the importance of stabilization related benefits is statistically significant, was partially confirmed. This finding is not surprising as young people who have small children are statistically significantly more interested and their interest in preschool allowance is, of course, logical.

There are also differences in the assessment of the importance of benefits in the distribution by gender, where all the benefits are more important for women. The significant differences (Table 3 ) can be found in paid leave and extra leave, and the benefit of flexible working hours is on the borderline of significance.

Table 3. Importance of benefits in relation to remaining in company - according to gender

\begin{tabular}{|c|c|c|c|c|c|c|}
\hline Benefits & Gender & $\begin{array}{c}\text { Mean } \\
\text { Rank }\end{array}$ & Mean & $\begin{array}{c}\text { Standard } \\
\text { Deviation }\end{array}$ & $\begin{array}{c}\text { Kruskal- } \\
\text { Wallis H }\end{array}$ & Sig. \\
\hline Paid leave & $\begin{array}{c}\text { Man } \\
\text { woman }\end{array}$ & $\begin{array}{c}71.90 \\
99.71\end{array}$ & 4.2 & 1.7 & 9.9 & $0.002^{* *}$ \\
\hline Extra leave & $\begin{array}{c}\text { Man } \\
\text { woman }\end{array}$ & $\begin{array}{c}73.01 \\
95.31\end{array}$ & 6.2 & 1.2 & 7.7 & $0.005^{* *}$ \\
\hline $\begin{array}{c}\text { Flexible } \\
\text { working hours }\end{array}$ & $\begin{array}{c}\text { Man } \\
\text { woman }\end{array}$ & $\begin{array}{c}74.74 \\
88.45\end{array}$ & 6.5 & 1.0 & 3.6 & 0.059 \\
\hline
\end{tabular}

Note: N=154; Correlation is significant at 0.01-** level; Sig. = Significance

Source: Own calculation

The third hypothesis assumed that the relationship between gender and the assessment of the importance of stabilization related benefits is statistically significant. This was confirmed for the two above-mentioned items and one on the borderline of significance.

Finally, a calculation was performed to verify whether there are differences in the assessment of the importance of benefits depending on the number of years spent in a company (Table 4). From this point of view, statistical significance was found only at the borderline values with significance at the 0.05 level. This applies to the benefit of the contribution to the nursery/kindergarten allowance and home office, which are more important for employees who have been working for the company for 1-5 years.

Table 4. Importance of benefits in relation to remaining in company - according to number of years in the company

\begin{tabular}{|c|c|c|c|c|c|c|}
\hline Benefits & $\begin{array}{c}\text { Number of } \\
\text { years }\end{array}$ & $\begin{array}{c}\text { Mean } \\
\text { Rank }\end{array}$ & Mean & $\begin{array}{c}\text { Standard } \\
\text { Deviation }\end{array}$ & $\begin{array}{c}\text { Kruskal- } \\
\text { Wallis H }\end{array}$ & Sig. \\
\hline $\begin{array}{c}\text { Nursery/ } \\
\text { kindergarten } \\
\text { allowance }\end{array}$ & $\begin{array}{c}1-5 \\
6-10\end{array}$ & 86.39 & & & & \\
$11-15$ & 79.48 & 2.4 & 1.7 & 10.6 & 0.059 \\
\hline
\end{tabular}




\begin{tabular}{|c|c|c|c|c|c|c|}
\hline & $21-25$ & 61.63 & & & & \\
\hline & $>25$ & 65.57 & & & & \\
Home office & $1-5$ & 87.75 & & & & \\
& $6-10$ & 71.08 & & & & \\
& $11-15$ & 86.55 & 5.7 & 1.8 & 10.1 & 0.073 \\
& $16-20$ & 63.07 & & & & \\
& $21-25$ & 62.13 & & & & \\
\hline
\end{tabular}

Note: N=154; Sig. = Significance

Source: Own calculation

These findings are not surprising. It can be assumed that the people belonging to the category $1-5$ years within this research are the same people as in the young age group, i.e. under 30 years old.

\section{FUTURE RESEARCH DIRECTIONS}

The research was focused on talented employees who work in the dynamically developing field of IT. In future research, it would be appropriate to focus on other professional groups, such as doctors, scientists, technicians, and others, as their benefit preferences may differ. It is probable that other professional groups will also be interested in the possibility of flexible working hours and other benefits that enable independent organization of working hours. This consideration is also confirmed by studies that already have been done and concentrated on similar issues. For example, flexible working hours for researchers at universities have been examined in more detail by Lytovchenko (2018). Other scientists also report on the positive effects of flexible working hours. Aries et al. (2019) found that if the employer allows flexible working hours, it significantly strengthens employee engagement. Flexible working hours are considered a competitive advantage by talented employees, which in turn has an impact on work performance (Galea, Houkes, \& De Rijk, 2014; Bukhari, Gupta, \& Taggar, 2018; and others).

This research found that benefits in W-L-B area are more important for women. In future research it would be appropriate to verify whether this finding is related to other roles that women take on (motherhood, home care, family care). Some studies have already addressed this issue not only in the context of W-L-B benefits, but also in the context of part-time work possibility (Beham, Baierl, \& Eckner, 2020). This opens up another interesting area of possible future research in the field of new forms of employment, such as shared jobs, etc.

\section{CONCLUSION}

Given that obtaining talented people is a very difficult and costly process for companies, it is essential that these employees receive increased attention. It is important to regularly determine their job satisfaction and respond quickly to the changing situation, needs and requirements of individual groups of employees. The results of this research show that within the W-L-B benefits group, IT specialists consider flexible working hours to be the most important benefit. In the area of W-L-B, the benefits that create more time for their personal lives are preferred by the employees. If employers want to recruit and further stabilize talented IT employees, they should create working conditions that allow them to saturate these needs.

The results also showed that other socio-economic factors are important when selecting benefits, such as the age of employees (for younger age groups, the benefits associated with 
caring for preschool children are important) and gender (women place more emphasis on WL-B benefits than men). If employers underestimate the care of talented groups of employees, the risk of brains leaving their company will increase significantly.

\section{ACKNOWLEDGMENT}

This research was supported by the Jan Evangelista Purkyně University in Ústí nad Labem [grant number UJEP-SGS-2020-45-005-3].

\section{REFERENCES}

Beham, B., Baierl, A., \& Eckner, J. (2020). When does part-time employment allow managers with family responsibilities to stay on the career track? A vignette study among German managers. European Management Journal, 38(4), 580-590. https://doi.org/10.1016/j.emj.2019.12.015

Bjärntoft, S., Hallman, D. M., Mathiassen, S. E., Larsson, J., \& Jahncke, H. (2020). Occupational and Individual Determinants of Work-life Balance among Office Workers with Flexible Work Arrangements. International Journal of Environmental Research and Public Health, 17(4). https://doi.org/10.3390/ijerph17041418

Bukhari, S. S., Gupta, M., \& Taggar, R. (2018). An Empirical Study on Employees Perception of Existing Flexible Work Practices and its Impact on their Performance. Amity Global HRM Review, 8(4), 36-39.

Crowley-Henry, M., Benson, E. T., \& Al Ariss, A. (2019). Linking Talent Management to Traditional and Boundaryless Career Orientations: Research Propositions and Future Directions. European Management Review, 16(1), 5-19. https://doi.org/10.1111/emre.12304

Drivas, K., Economidou, C., Karamanis, D., \& Sanders, M. (2020). Mobility of highly skilled individuals and local innovation activity. Technological Forecasting \& Social Change, 158, 120144. https://doi.org/10.1016/j.techfore.2020.120144

Galea, C., Houkes, I., \& De Rijk, A. (2014). An insider's point of view: how a system of flexible working hours helps employees to strike a proper balance between work and personal life. The International Journal of Human Resource Management, 25(8), 1090-1111. https://doi.org/10.1080/09585192.2013.816862

Gragnano, A., Simbula, S., \& Miglioretti, M. (2020). Work-Life Balance: Weighing the Importance of Work-Family and Work-Health Balance. International Journal of Environmental Research and Public Health, 17(3), 907. https://doi.org/10.3390/ijerph17030907

Kerdpitak, C., \& Jermsittiparsert, K. (2020). The Effects of Workplace Stress, Work-Life Balance on Turnover Intention: An Empirical Evidence from Pharmaceutical Industry in Thailand. Systematic Reviews in Pharmacy, 11(2), 586-594. https://doi.org/10.5530/srp.2020.2.86

Lytovchenko, I. V. (2018). The Organizational-Legal Peculiarities of Application of the Remote Labor Mode and Flexible Working Hours of Scientific Workers at Higher Education Institution. Biznes Inform, 1(480), 182-187.

Mensah, A., \& Adjei, N. K. (2020). Work-life balance and self-reported health among working adults in Europe: a gender and welfare state regime comparative analysis. BMC Public Health, 20(1), 1-14. https://doi.org/10.1186/s12889-020-09139-w

Meyer, K. E., \& Xin, K. R. (2018). Managing talent in emerging economy multinationals: integrating strategic management and human resource management. International 
Journal of Human Resource Management, 29(11), 1827-1855. https://doi.org/10.1080/09585192.2017.1336362

Pawlicka, A., Pawlicki, M., Tomaszewska, R., Choraś, M., \& Gerlach, R. (2020). Innovative machine learning approach and evaluation campaign for predicting the subjective feeling of work-life balance among employees. PLoS ONE, 15(5), e0232771. https://doi.org/10.1371/journal.pone.0232771

Przytuła, S. (2018). Global Talent Management in the Context of Expatriation. Human Resource Management / Zarzadzanie Zasobami Ludzkimi, 125(6), 29-49.

Rodríguez-Sánchez, J.-L., González-Torres, T., Montero-Navarro, A., \& Gallego-Losada, R. (2020). Investing Time and Resources for Work-Life Balance: The Effect on Talent Retention. International Journal of Environmental Research and Public Health, 17(6), 1920. https://doi.org/10.3390/ijerph17061920

Setiyani, A., Djumarno, D., Riyanto, S., \& Nawangsari, L. (2019). The Effect of Work Environment on Flexible Working Hours, Employee Engagement and Employee Motivation. International Review of Management and Marketing, 9(3), 112-116.

Slavković, M., Babić, V., \& Stojanović-Aleksić, V. (2015). Talent Management: Opportunities and Limitations for Serbian Organizations. TEME: Casopis Za Društvene Nauke, 39(2), 361-379.

Vetráková, M., Šimočková, I., Kubal'a, J., \& Malachovský, A. (2020). How to Establish Talented Employees in Slovak Companies. Periodica Polytechnica: Social \& Management Sciences, 28(2), 29-37. https://doi.org/10.3311/PPso.13269

Zimmerman, R. D., Swider, B. W., \& Arthur, J. B. (2020). Does turnover destination matter? Differentiating antecedents of occupational change versus organizational change. Journal of Vocational Behavior, 121, 103470. https://doi.org/10.1016/j.jvb.2020.103470 